\title{
ADDITIONAL NOTES ON THE ORB-WEAVER GENERA ARANEUS, HYPSOSINGA, AND SINGA NORTH OF MEXICO (ARANEAE, ARANEIDAE)*
}

\author{
By Herbert W. Levi \\ Museum of Comparative Zoology, Harvard University
}

\section{INTRODUCTION}

After my first Araneus study was published in 197 I I was informed by W. J. Gertsch and V. Roth that the males of $A$. illaudatus are found with females of my newly described $A$. pima. However, owing to the great size difference and abdominal pattern difference, I remained stubbornly unconvinced that they could belong to the same species until spiderlings from an egg-sac raised by $\mathrm{P}$. Witt grew up into female $A$. pima and male $A$. illaudatus. This persuaded me but raised some new questions, as the hand-reared males are larger, the females smaller, than in wild populations (see below).

While establishing this synonymy (in Levi, 197I), I take this opportunity to report on an additional new species of Araneus from the Southwest (Levi, I973), as well as to report range extensions from the American Museum Singa and additional Araneus collections and from the R. V. Chamberlin (University of Utah) collection, now again available. I will publish later on a number of tiny new species of Araneus, most collected as provisions by wasps.

I would like to thank W. J. Gertsch, V. Roth, N. Platnick, of the American Museum of Natural History, S. Frommer, F. Enders and P. Witt for specimens, E. Mayr and Lorna R. Levi for reading the manuscript. National Science Foundation Grant BMS 75-057 I9 supported the researches and publication.

\section{Size Variations}

For unknown reasons, size differences between sexes and among individuals of the same sex within populations are much greater in orb-weavers in the superfamily Araneoidea than in other spiders, although adult size variations are common in arachnids. These differences, due to variation in the number of instars before maturity, have been commented on by others (e.g. Gerhardt, I929, I930; Probst, 1972 in Isometrus scorpions).

*Manuscript received by the editor September 10, 1975 
Since large differences in size may be accompanied by allometric differences it often becomes very difficult to decide whether a large and a small female belong to the same species. Also, the large and small specimens have differences in numbers of macrosetae.

In addition, in the Araneidae there are often large differences in size between the sexes as the dwarfed males mature already after only a few molts, sometimes after fewer than half the number in females. Larger males, having undergone more molts, may resemble females more than they resemble smaller males (Gerhardt, 1929).

Oddly, the smallest female and one of the larger males of $A$. illaudatus came out of the same egg-sac, hand-raised in P. Witt's laboratory in North Carolina. This poses the question, to what extent the variable number of instars is environmentally determined? The egg-sac came from a building of the Southwestern Research Station near Portal, Arizona, where males are usually small and females large.

According to older literature the minute size of many male orbweavers prevents suitors from being mistaken for prey by the large female. This idea, which originated with Charles Darwin and Friedrich Dahl (Gerhardt, 1929), is not convincing to me. In Gerhardt's experiments neither large nor small males were attacked. It is much more likely that the differences in size, especially in warm climate spiders, is a secondary by-product of selection for different rates of ontogeny. A quick maturation of males, etc. is an adaptation against inbreeding. The tiny males mature after a few molts, perhaps months before sibling females undergo their 8 to II instars, and are forced to look for mature females from earlier broods or even from a different generation. [Witt (personal communication) reports that in his cultures of Araneus diadematus males mature long before females.] But then why do small males come in various sizes (as in A. illaudatus), and why do hand-raised females vary in size? Is there genetic polymorphism for rate of development?

Figs. 1-4. Left palpus, apical view. 1. Araneus gemmoides Chamberlin and Ivie. 2. Araneus gemma (McCook). 3, 4. Araneus illaudatus (Gertsch and Mulaik). 3. (Portal, Arizona). 4. (hand-raised specimen, Portal, Arizona).

Figs. 5-11. Araneus abigeatus new species. 5-8. Epigynum. 5. Ventral view, cleared. 6. Ventral view. 7. Posterior view, cleared. 8. Posterior view. 9-11. Left palpus. 9. Mesal. 10. Ventral. 11. Embolus in mesal view.

Size indicators, $0.1 \mathrm{~mm}$. 

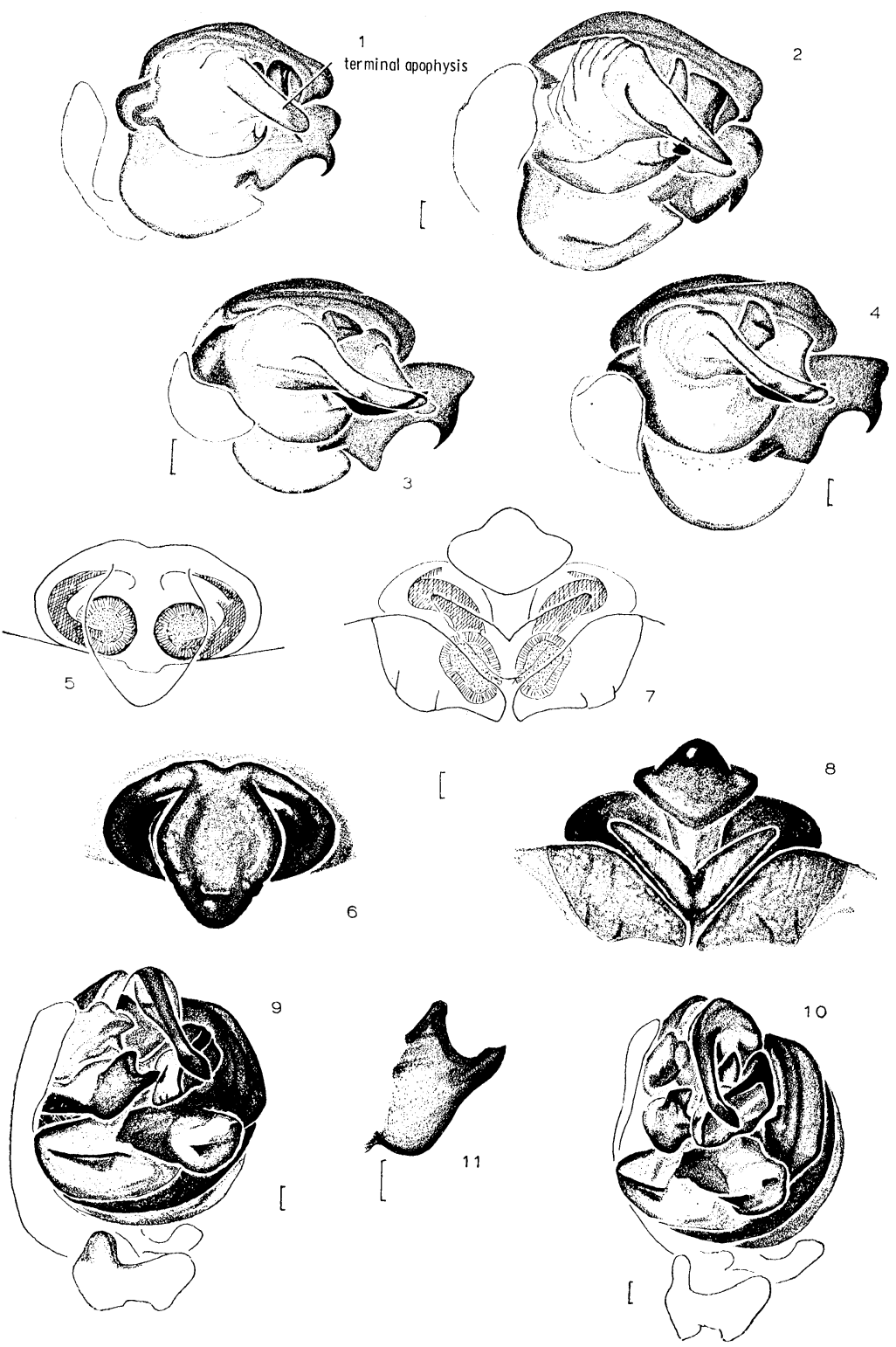


\section{Araneus illaudatus (Gertsch and Mulaik)}

Figures 3, 4

Aranea illaudata Gertsch and Mulaik, 1936, Amer. Mus. Novitates, no. 863, p. 19, figs. 36, 37, ô. Male holotype from Edinburg, Texas in the American Museum of Natural History, examined.

Araneus pima Levi, 1971, Bull. Mus. Comp. Zool., vol. 141, p. 176, plates 1, 4, figs. 218-232, + , $\hat{o}$, map 8. Female holotype from Madera Canyon, Santa Rita Mountains, Pima Co., Arizona in the American Museum of Natural History. NEW SYNONYMY.

Araneus illaudatus, - Levi, 1971, Bull. Mus. Comp. Zool., vol. 141, p. 176, figs. $238-240$, of (not figs. 233-237, + which is $A$. abigeatus, n. sp.).

Note. Some $A$. illaudatus males had shorter embolus caps than others. The distribution maps (Levi, I97 I) of $A$. illaudatus and $A$. pima should be combined.

Diagnosis. Males of the three similar species can be separated by the length of the terminal apophysis in apical view. Araneus gemmoides Chamberlin and Ivie has the shortest, widest terminal apophysis (Fig. I) and largest palpal tibia ( I97 I, figs. I99-200). Araneus gemma (McCook) has a pointed, curved terminal apophysis, widest at the base (Fig. 2). Araneus illaudatus has a long curved terminal apophysis, the sides more or less parallel (Figs. 3, 4).

Size ranges. Total length of females varied II.5 to $27 \mathrm{~mm}$. The smallest female was hand-raised from Chihuahua Mts., Arizona and another collected at Gateway, Oregon, both II.5 mm. Total length of California females in $\mathrm{mm}$ : 14, I7, 22; Utah: 13, 23; Arizona, Fort Grant: 22; Huachuca Mts.: I8, I8, I8, 20, 23; Chihuahua Mts.: I3, I9, 21, 22, 23; Santa Rita Mts.: I8, 20, 24; Grand Canyon: I5; Texas: I4, I8; Mexico, Chihuahua: i8. Not all females were measured, only one from each collection. There appears to be no geographic pattern.

Total length of males 2.9 to $7.9 \mathrm{~mm}$. Measurements of males in $\mathrm{mm}$ : Utah, Watson: total length 4.2, carapace 1.9 long, I.5 wide; Arizona, Santa Rita Mtns.: total length 7.9, carapace 4.I long, 3.0 wide; Chihuahua Mts.: total length 2.9 to $3.9 \mathrm{~mm}$, carapace I.6 to 1.9 long, I.2 to I.6 wide, three specimens; Texas: total length 3.6 to $4.0 \mathrm{~mm}$, carapace $\mathrm{I} .9$ to 2.0 long, I.3 to $\mathrm{I} .5$ wide, two specimens; specimen from Chihuahua Mts. hand-raised in North Carolina: total length $6.6 \mathrm{~mm}$, carapace 3.6 long, 2.8 wide (Fig. 4). All males were measured; the $6.6 \mathrm{~mm}$ and $3.8 \mathrm{~mm}$ males are illustrated in Figures 3, 4 . 


\section{Araneus abigeatus new species}

Figures 5-I I

Araneus illaudatus, - Levi, 1971, Bull. Mus. Comp. Zool., vol. 141, p. 176, figs. 233-237, 으, epigynum and abdomen; not figs. 238-240, ô.

Holotype. Female from Rustler Camp, Chiricahua Mts., Cochise Co., Arizona, 9 Sept. I950 (W. J. Gertsch) in the American Museum of Natural History. The name abigeatus is a Latin verb for cattle stealing, rustling.

Description. Female. Carapace dark brown, marbled on lighter brown with some light setae. Sternum dark brown, coxae light. Legs banded brown on yellow-white with some white-tipped setae. Dorsum of abdomen with a median longitudinal line of white spots and four pairs of dark brown chevrons, the posterior pair fused in middle on dark brown speckled background ( I97 I, fig. 236). Venter with a black band from epigynum to spinnerets, and a pair of white spots side by side. Spinnerets dark brown. Eyes subequal in size. Anterior median eyes slightly more than their diameter apart. The abdomen has a pair of anterior dorsal humps. Total length I I.O mm. Carapace $3.7 \mathrm{~mm}$ long, 3.5 wide. First femur, $4.5 \mathrm{~mm}$; patella and tibia, 5.5; metatarsus, 3.7 ; tarsus, I.4. Second patella and tibia, $5.0 \mathrm{~mm}$; third, 2.9 ; fourth, 4.9 .

Male. Coloration similar to that of female, except carapace more uniform light brown. Thorax with a longitudinal groove. Eye size and spacing as in female. First coxa with a hook, second femur with groove. Second coxa with a small posterior, proximal tubercle, no spur. Second tibia swollen with macrosetae on venter. Total length $7.0 \mathrm{~mm}$. Carapace $3.8 \mathrm{~mm}$ long, 3.2 wide First femur, $5.0 \mathrm{~mm}$; patella and tibia, 6.5; metatarsus, 3.6; tarsus, I.3. Second patella and tibia, $5.0 \mathrm{~mm}$; third, 2.9 ; fourth, 4.5 .

Diagnosis. The constricted neck of the scape of the epigynum covering a large hollow space (Figs. 6, 8) separates this species from Araneus illaudatus. The internal genitalia (Figs. 5, 7) are heavily sclerotized and were cleared but not macerated as only few specimens were available.

The male will key out to $A$. washingtoni in Levi (197I) but the palpus is similar to that of $A$. nordmanni. The palpus has a terminal apophysis prong similar to that of $A$. nordmanni but differs by the shape of the shorter embolus (Fig. II) and shape of conductor (Figs. 9, IO).

Records. Known from type locality only. Paratypes collected on 25 Aug. I952, I + (B. Malkin), 23 Aug. I968, I 우 (V. Roth), 4 Aug. 1973, + , ơ (S. Frommer). 


\section{Araneus washingtoni Levi}

Additional Record. Ontario: Batchawana, $0^{\pi}$.

Araneus santarita (Archer)

Additional Record. Arizona: Cochise Co.: Upper Cave Creek, Chiricahua Mts. (V. Roth).

\section{Araneus pratensis (Emerton)}

Additional Records. Ontario: Thessalon. Mississippi: Wilkinson Co.: Centreville.

\section{Araneus mammatus (Archer)}

Additional Record. New Mexico: Santa Fe Co.: Hyde Memorial State Park, 8 miles northeast of Santa Fe.

\section{Araneus mariposa Levi}

Additional Record. Oregon: Jackson Co: Sams Valley to Dead Indian Spring, 2 ㅇ (J. Schuh).

\section{Araneus apache n. sp.}

Figures $12-20$

Type. Male holotype with a female paratype from Rustler Camp, Chiricahua Mts., 9 Sept. I950 (W. J. Gertsch) in the American Museum of Natural History.

Description of female paratype. Carapace yellow-white with a wide median longitudinal brown band pointed posteriorly toward thoracic depression. Sternum brownish black. Legs with dark bands. Coxae yellow-white. Dorsum of abdomen with transverse marks as in Figure I7. Venter brownish black with transverse white mark behind epigynum (Fig. I6). Posterior median eyes subequal to anterior medians. Anterior laterals 0.8 , posterior laterals 0.9 diameters of anterior medians. Anterior median eyes I.4 diameter apart, I.6 from laterals. Posterior median eyes slightly less than their diameter apart. The height of the clypeus is less than diameter of anterior median eyes. Abdomen is almost round, dorso-ventrally slightly flattened. Total length $7.5 \mathrm{~mm}$. Carapace $3.1 \mathrm{~mm}$ long, 2.4 wide. First femur, $3.2 \mathrm{~mm}$; patella and tibia, 4.2 ; metatarsus, 3.0; tarsus, I.O. Second patella and tibia, $3.4 \mathrm{~mm}$; third, 2.0; fourth, 3.0 

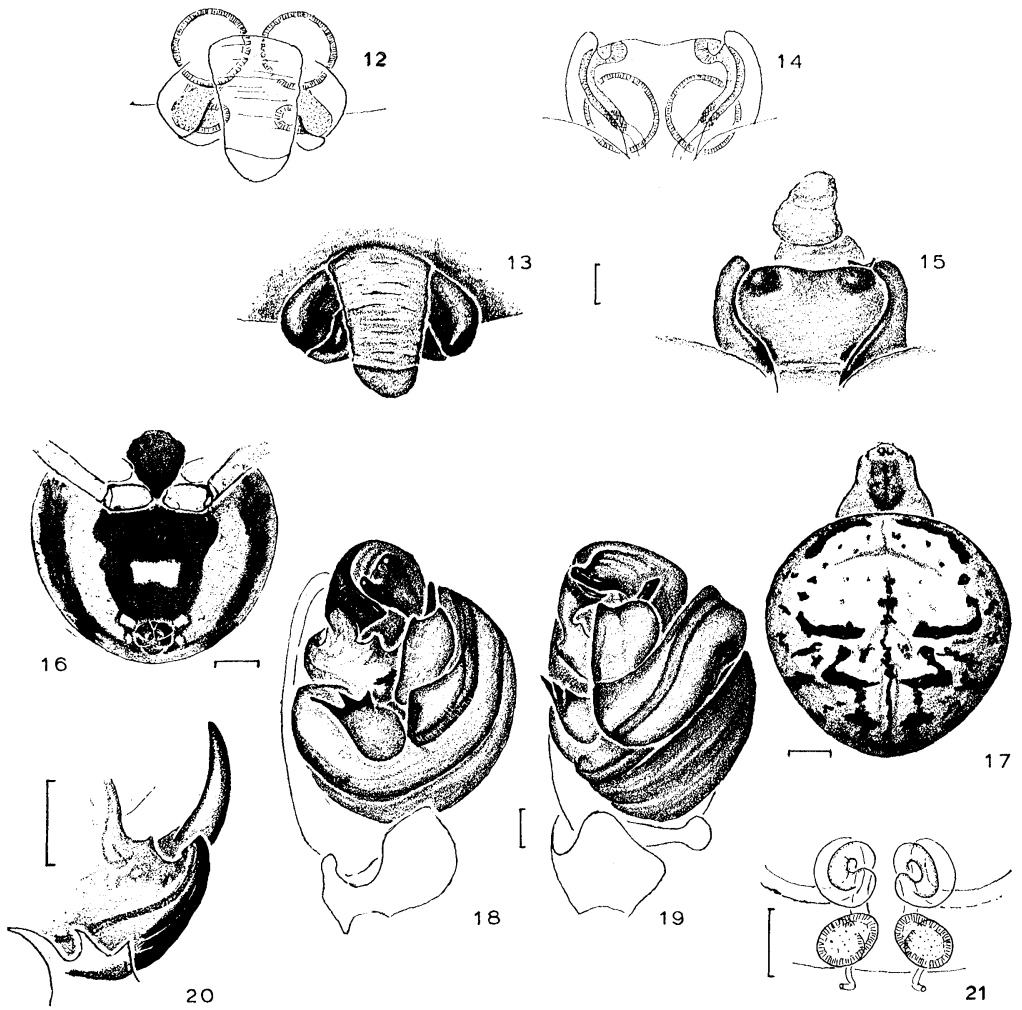

Figs. 12-20. Araneus apache new species. 12-15. Epigynum. 12. Ventral view, cleared. 13. Ventral view. 14. Posterior view, cleared. 15. Posterior view. 16. Female abdomen, ventral. 17. Female carapace and abdomen, dorsal. 18-20. Left male palpus. 18. Subventral view. 19. Ventral view. 20. Embolus, subventral view.

Fig. 21. Hypsosinga pygmaea (Sundevall), dorsal view of genitalia.

Size indicators, $0.1 \mathrm{~mm}$, except Figs. 16, 17, $1.0 \mathrm{~mm}$. 
Males. Males are less distinctly marked than females. The eye size ratios and distances are about the same as those of female. The first coxa has a hook, the second tibia has macrosetae but is not swollen. Total length $4.0 \mathrm{~mm}$. Carapace $2.3 \mathrm{~mm}$ long, 1.9 wide. Second patella and tibia, $3.0 \mathrm{~mm}$; third, I.7; fourth, 2.5 .

Variation. There is little variation in size of the few specimens available. The dorsum is much lighter in some individuals than in others; and in the pale specimens, the median carapace band and the dark spots on the abdomen barely show. All, however, have a dark sternum.

Diagnosis. This species is close to Araneus pegnia (Walckenaer), but males differ by having three prongs on the median apophysis (Fig. I8) rather than two and in details of the shape of other distal palpal structures (Figs. 18-20). Females differ from those of $A$. pegnia by having a wider scape (Fig. 13) and also a brownish black sternum and brownish black venter of the abdomen surrounding a transverse white mark (Fig. I6). Males differ from those of $A$. thaddeus, which have a similar three-pronged median apophysis, by the very differently shaped embolus (Fig. 20), bearing a wormshaped lamella. Such an embolus lamella is present in $A$. pegnia also, but is not illustrated in Levi (1973, figs. 436, 437).

The species keys out to $3, A$. pegnia and $A$. thaddeus, in my key to females of smaller species of Araneus (Levi, I973, p. 488) and to 3 A. thaddeus in my key to males of smaller species of Araneus (Levi, I973, p. 489).

Note. This is not $A$. montanus Archer. The holotype of $A$. montanus was re-examined and is $A$. thaddeus as synonymized before (Levi, 1973). Females of $A$. apache I had previously placed in A. pegnia. Araneus pegnia does not seem to occur in southeastern Arizona; it is found in California and Sonora (Levi, 1973, map 6).

Records. Paratypes from Arizona. Cochise Co.: Chiricahua Mts., 29 Aug. 1938, ơ (R. H. Crandall). Graham Co.: Pinecrest, Graham Mt., 13 Sept. 1950, 2 ㅇ (W. J. Gertsch), Shannon Camp. Graham Mt., I3 Sept. 1950, 5 o (W. J. Gertsch). Pima Co.: Santa Catalina Mts., 5 Sept. 1938, 2 † (R. H. Crandall).

\section{Singa keyserlingi McCook}

Additional Records. New Jersey. Ocean Co.: Lakehurst. Burlington Co.: Lebanon State Forest. Minnesota. Goodhue Co.: Lake Pepin. Carlton Co.: Carlton. 
Singa eugeni Levi

Additional Records. New York. Kings Co.: Bergen Beach (Brooklyn). New Jersey. Atlantic Co.: Oceanville. North Carolina. Carteret Co.: Beaufort.

\section{Hypsosinga pygmaea (Sundevall)}

Figure 2I

Theridion pygmaea Sundevall, 1831, Kongl. Svenska Vet. Akad. Handl. p. 121. Type from Sweden, assumed lost.

Singa variabilis Emerton, 1884, Trans. Connecticut Acad. Sci., vol. 6, p. 322, pl. 34, fig. 16, pl. 37, figs, 19-21, 우, $\hat{o}$. Five syntypes from New Haven, Connecticut in the Museum of Comparative Zoology. NEW SYNONYMY.

Singa pygmaea, - Wiehle, 1931 in Dahl, Tierwelt Deutschland, vol. 23, p. 47, figs. 64, 65, 우 $\hat{o}$. Roewer, 1942, Katalog der Araneae, vol. 1, p. 875. Locket and Millidge, 1953, British Spiders, vol. 2, p. 155, figs. $102 \mathrm{c}, 103 \mathrm{~b}, 104 \mathrm{~b}$, 우, 수.

Hypsosinga variabilis, - Levi, 1972, Psyche, vol. 78, p. 242, figs. 44-57, ㅇ, $\hat{o}, \operatorname{map} 2$.

Note. Mr. G. H. Locket recently lent me British specimens of this species and they turned out to be the same as our common $H$. variabilis. There are only minor, probably geographic, differences.

Distribution. The distribution of this species is holarctic. The synonymy of $H$. variabilis with $H$. pygmaea was overlooked previously.

Additional American Records. Nova Scotia. Berwick. Tennessee. Lake Co.: Reelfoot Lake. Georgia. Chatham Co.: 3 mi. southeast of Savannah. Nebraska. Loup Co.: Taylor. Wyoming. Yellowstone Natl. Park: Yellowstone Lake. Grand Teton Natl. Park: Moran. Utah. Salt Lake Co.: Salt Lake City. Cuba. Pinar del Río: Viñales.

\section{Hypsosinga funebris (Keyserling)}

Cercidia funebris Keyserling, 1893, Spinnen Amerikas, vol. 4, p. 37, pl. 2, fig. 32, ㅇ. Female holotype from Crescent City, Florida, Marx collection of the United States National Museum kept in the American Museum of Natural History, examined.

Araneus singaeformis Scheffer, 1904, Entomol. News, vol. 15, p. 259, pl. 77, figs. 4-6, o. Female syntypes from Wallace County, Kansas in the Museum of Comparative Zoology.

Hypsosinga singaeformis, - Levi, 1972, Psyche, vol. 78, p. 246, figs. 58-71, , î. Map 3. 
Additional Records. Alberta. Medicine Hat. Maine. Acadia Natl. Park: Mt. Desert Island. Connecticut. South Meriden. New Jersey. Ocean Co.: Lakehurst. Tennessee. Bedford Co.: Shelbyville. Minnesota Carlton Co.: Barnum. Texas. Kerr Co.: Kerrville. Hildalgo Co.: Edinburg. Utah. Salt Lake Co.: Alta. California. Monterey Co.: Monterey.

\section{Hypsosinga alberta Levi}

Additional Record. Yukon Territory. South shore, Atlin Lake, willow, heath, dwarf shrubs, 20 Aug. 1974, ㅇ (D. E. Bixler).

\section{Hypsosinga groenlandica Simon}

Additional Record. Yukon Territory. Herschel, 24 July I97I (W. R. M. Mason). Utah. Cache Co.: Franklin Basin, I6 July 1975, I o (G. F. Knowlton).

\section{References Cited}

GERHARDT, U.

1929. Über Grössenvarianten der Männchen von Nephila madagascariensis Vinson. Zool. Anz. vol. 86, p. 80-82.

1930. Biologische Beobachtungen an Nephila madagascariensis Vins. LEvr, H. W.

Sitzungsber. Gesellsch. naturforsch. Freunde Berlin, p. 358-360.

1971. The Diadematus Group of the Orb-Weaver Genus Araneus North of Mexico (Araneae: Araneidae). Bull. Mus. Comp. Zool. vol. 141, p. 131-179.

1972. The Orb-Weaver genera Singa and Hypsosinga in America (Araneae: Araneidae). Psyche, vol. 78, p. 229-256.

1973. Small Orb-Weavers of the Genus Araneus North of Mexico (Araneae: Araneidae). Bull. Mus. Comp. Zool. vol. 145, p. 473-

Probst, P. 552.

1972. Zur Fortpflanzungsbiologie und zur Entwicklung der Giftdrüsen beim Skorpion Isometrus maculatus (DeGeer, 1778). Acta Tropica, vol. 29 , p. 1-87. 

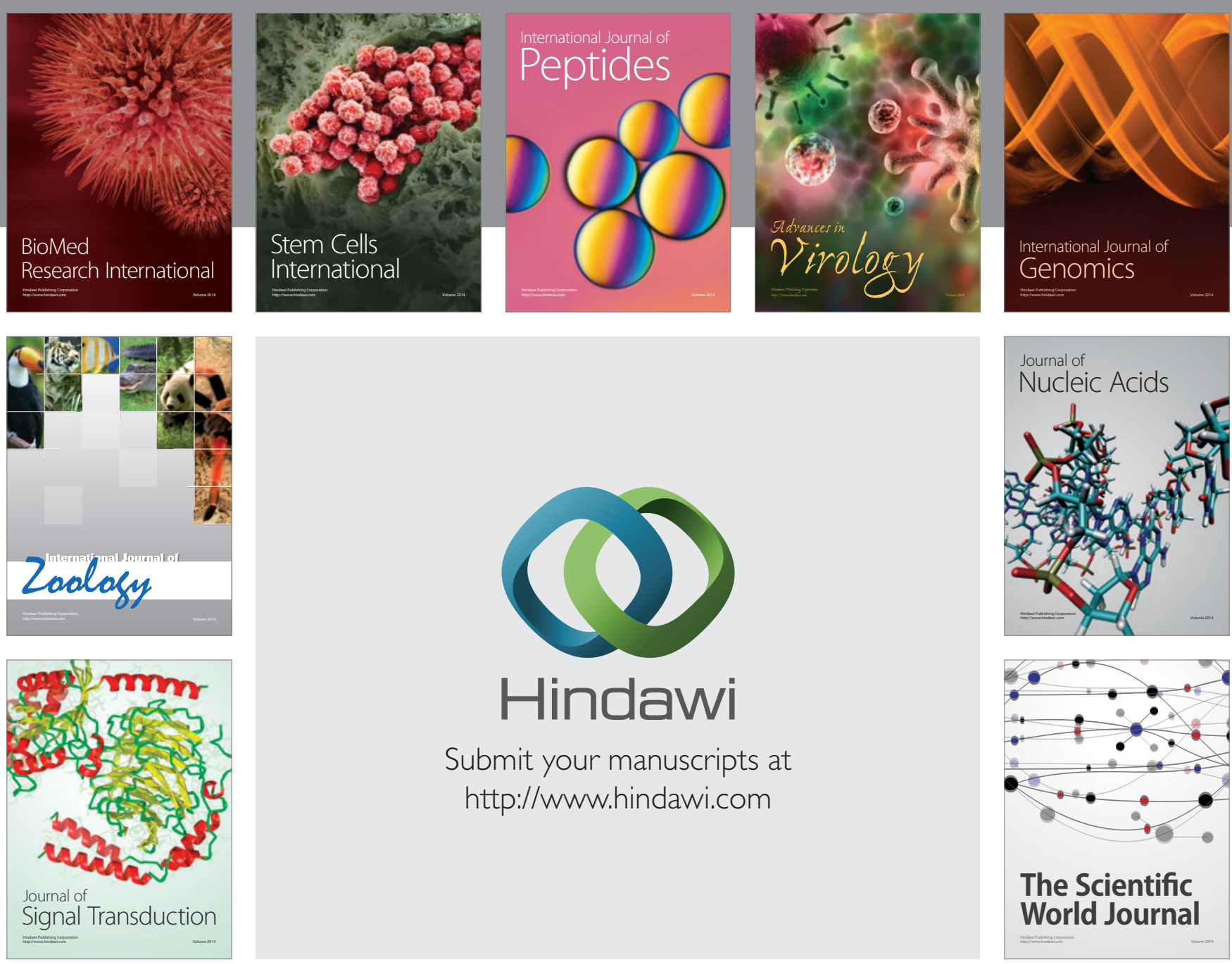

Submit your manuscripts at

http://www.hindawi.com
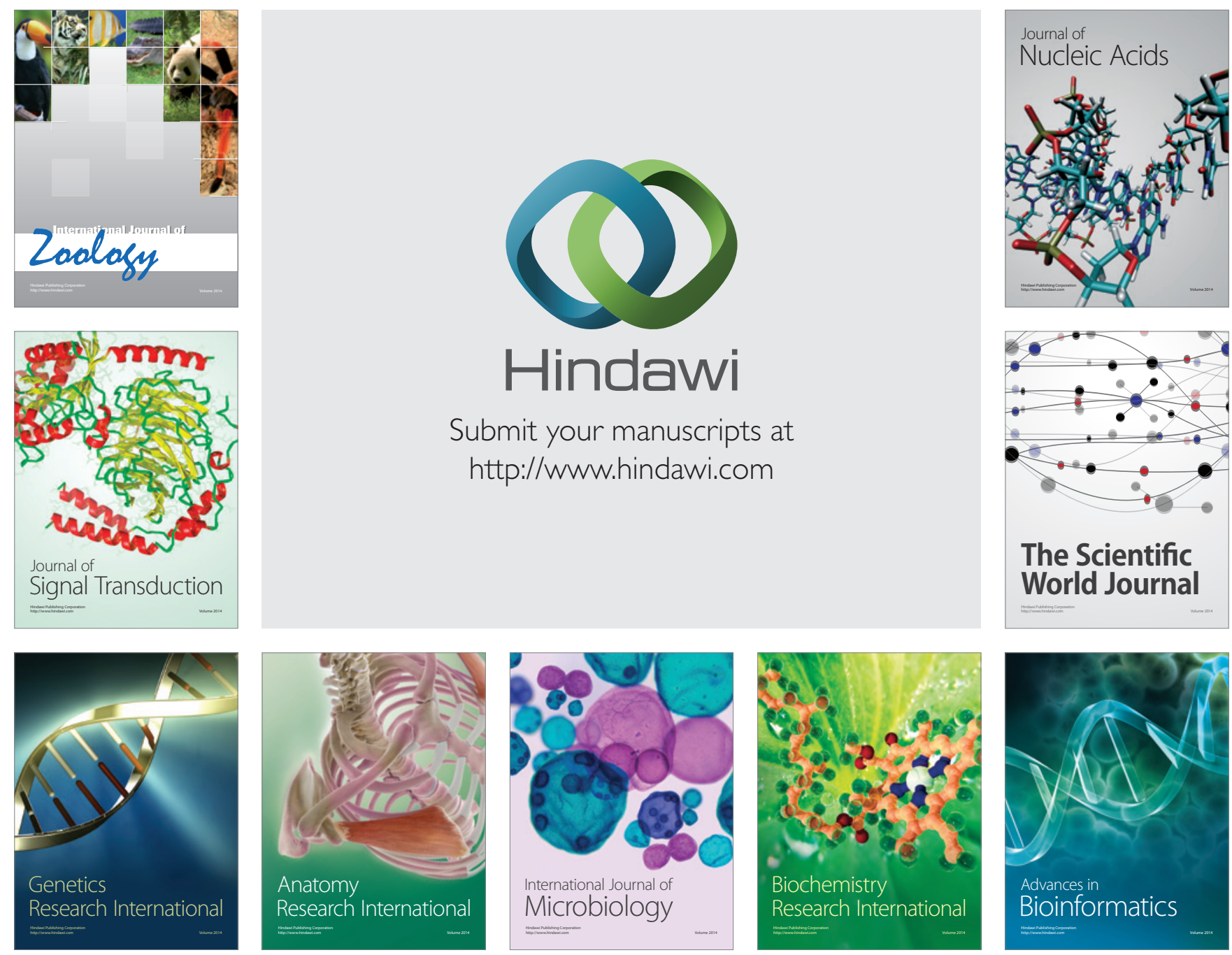

The Scientific World Journal
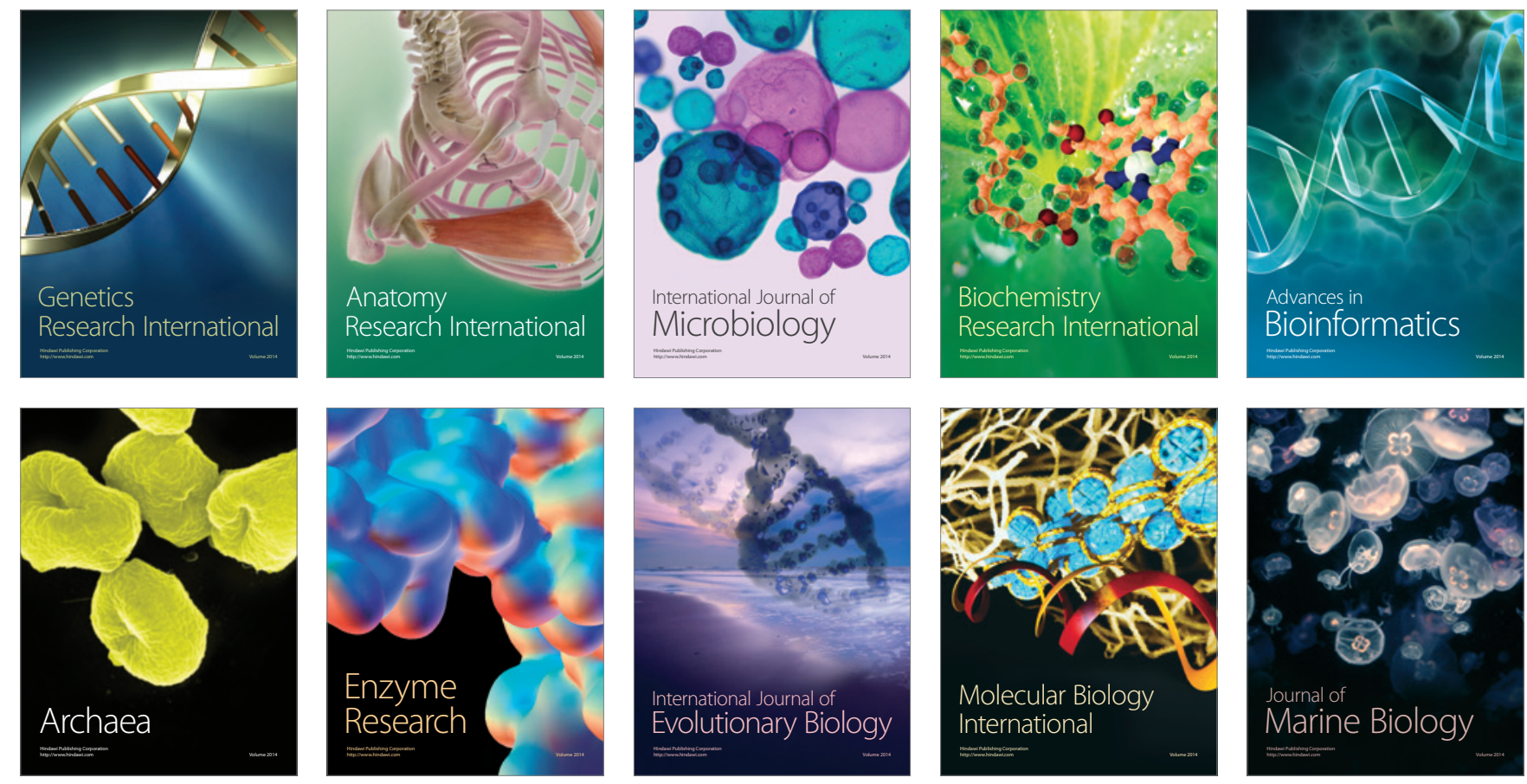